\title{
Revision of the circumglobal deep-sea genus Leucicorus (Teleostei, Ophidiidae) with two new species
}

\author{
WERNER W. SCHWARZHANS ${ }^{1 *}$, JØRGEN G. NIELSEN ${ }^{2} \&$ BRUCE C. MUNDY ${ }^{3}$ \\ ${ }^{1}$ Zoological Museum, Natural History Museum of Denmark, Universitetsparken 15, 2100 Copenhagen Ø, Denmark and Ahrensburger \\ Weg 103, 22359 Hamburg, Germany \\ ${ }^{2}$ Zoological Museum, Natural History Museum of Denmark, Universitetsparken 15, 2100 Copenhagen Ø, Denmark. \\ ఏ"jgnielsen@snm.ku.dk \\ ${ }^{3}$ Ocean Research Explorations, P.O. Box 235926, Honolulu, HI 96823, USA. $\equiv$ mundyichthyo@gmail.com \\ "Corresponding author. ="wwschwarz@aol.com; @i http://orcid.org/0000-0003-4842-7989
}

\begin{abstract}
The rare deepsea ophidiid genus Leucicorus was described by Garman (1899) based on L. lusciosus Garman, 1899 caught in the East Pacific. Until 1973 only three additional specimens were caught of which two from the East Pacific belong to L. lusciosus and one from off Hawai $\mathrm{i}$ is an undescribed species here described as L. lentibus $\mathbf{n}$. sp. In 1973 a Soviet expedition to the Caribbean Sea trawled 18 specimens from abyssal and hadal depths and based on this material a second Leucicorus species was described, L. atlanticus Nielsen, 1975. Since then eight Leucicorus specimens from the Indo-Pacific and Atlantic Oceans have been caught of which two from the West Atlantic belong to a new species, $L$. gerringerae n. sp., herein described, four to L. atlanticus and two remain as Leucicorus sp. About 35 demersal Leucicorus specimens have been observed and photographed by ROV (remotely operated vehicle) at depths of 3804-5768 meters in the Pacific Ocean.
\end{abstract}

Key words: Teleostei, Ophidiidae, Leucicorus, photo observations, two new species, otoliths

\section{Introduction}

The fishes of the genus Leucicorus are among the deepest dwelling vertebrates in the oceans (Gerringer, 2019), mostly occurring benthopelagically over abyssal plains or at seamounts and occasionally venturing into hadal depths (Gerringer et al., 2021). Our generic revision is based on 30 specimens of which 22 were caught at abyssal depths (more than $4000 \mathrm{~m}$ ), five at hadal depth the deepest at a depth of $6800 \mathrm{~m}$, and three specimens of L. lusciosus at a bathyal depth of 2710 to $4000 \mathrm{~m}$. Two species were previously described, L. lusciosus Garman, 1899 known from three specimens from the Pacific Ocean and L. atlanticus Nielsen, 1975 known from 21 Atlantic specimens. Two Atlantic specimens form the basis for a new species, L. gerringerae $\mathbf{n}$. sp. and one specimen from off Hawai $i$ forms the basis for a second new species, L. lentibus n. sp. Both are described herein. One specimen from the Solomon Sea is referred to L. atlanticus and two from the Arabian Sea are left as Leucicorus sp. Furthermore, about 35 Leucicorus specimens have been observed and photographed by Remotely Operated Vehicles (ROVs) from at least 9 areas in the Pacific at depths between 3804- $5768 \mathrm{~m}$. A few of these could be referred to L. lusciosus.

\section{Material and methods}

The material was caught in bottom trawls at depths of 2710-6800 $\mathrm{m}$ so the very fragile head bones were often torn. Ichthyological terminology and counts follow Nielsen et al. (1999). Institutional abbreviations follow Fricke \& Eschmeyer (2021).

Observations of live Leucicorus, in their environment, were obtained in the Pacific Ocean during the 2015-2017 expeditions of the NOAA ship Okeanos Explorer during its Campaign to Address Pacific Monument Science, Tech- 
nology, and Ocean Needs (CAPSTONE). The surveys focused on ridges and seamounts, not sedimented habitats. Regions surveyed were: the Hawaiian Archipelago, Johnston Atoll, the Karin Ridge, the Geologist Seamounts to the southwest of the main Hawaiian Islands, the Musician Seamounts to the east of the Hawaiian Islands, the Mariana Archipelago, Wake Atoll, American Sâmoa, Swains Island, Howland and Baker Islands, the Phoenix Islands Protected Areas, the Tokelau Islands region, Marae Moana (the Cook Islands Marine Park), and Jarvis Island, Kingman Reef, and Palmyra Atoll in the Line Islands (Kennedy et al., 2019)

The CAPSTONE surveys were conducted with a two-stage ROV system, rated to a maximum depth of $6000 \mathrm{~m}$, tethered to the ship with a $1.73 \mathrm{~cm}$ diameter armored fiber-optic cable for data and image transmission (Quattrini et al., 2015). The lower stage (D2) usually moved at $<1-1.5 \mathrm{~m}$ above the bottom at $3-9 \mathrm{~m} / \mathrm{min}$ (Kennedy et al., 2019), but could stop for close observations. Sample collection was limited to stationary objects, with no ability to collect fishes (Gregory et al., 2016). Sensors of an integrated navigation system on D2 allowed for precise maneuvering and data capture of the position, depth, and elevation above bottom. Temperature, conductivity (for salinity) and dissolved oxygen data at depth were collected with Sea-bird 911+ conductivity-temperature-depth (CTD) loggers attached to both stages (Quattrini et al., 2015). The ROV dives typically were for 8-10+ hours, but time on the bottom varied between 2-7 hours. Travel time to and from the bottom varied with depth, with deeper dives having less bottom time than shallower dives. Observations of Leucicorus were during short, deep dives. The D2 had two high-definition, maneuverable Mini Zeus video cameras that could zoom in for extreme close-ups of organisms. Two parallel lasers mounted on one of the cameras were set at a distance of $10 \mathrm{~cm}$ apart, directed within the camera's field of view to allow of the sizes of objects to be estimated (Quattrini et al., 2015).

After the dives, the video records were analyzed and observations of organisms were tabulated by the Hawai' $\mathrm{i}$ Undersea Research Laboratory, University of Hawai ${ }^{i}$ (Kennedy et al., 2019). Nineteen of the 187 dives during the expeditions were excluded from these analyses because they focused on midwater observations, marine archaeology, or engineering trials, leaving 168 sites with biological data (Kennedy et al., 2019). The identifications of organisms in the database were from those made by participating biologists during the dives by telepresence, including the third author, with later modifications from consultations with taxonomic experts, including the second author. The substrate during each observation was classified from the dive video and included in the database, in addition to the identifications, locations, dates, times, and data from the CTD on the ROV. Access to the images, videos, and data from the individual dives is available from the NOAA Ocean Exploration (previously the NOAA Office of Ocean Exploration and Research) digital atlas (https://www.ncei.noaa.gov/maps/oer-digital-atlas/mapsOE.htm; Mesick et al., 2016, 2017), with methods of access described at https:/oceanexplorer.noaa.gov/data/access/digitalatlas/digital-atlas.html.

Abbreviations. HL(head length), HT(holotype), OL(otolith length), OH(otolith height), OT(otter trawl), PT(paratype), SL(standard length).

\section{Systematics}

\section{Leucicorus Garman, 1899}

Leucicorus Garman, 1899: 146 (type species by monotypy Leucicorus lusciosus Garman, 1899). Leucicorus: Nielsen 1974: 348; Nielsen 1975: 106; Nielsen et al. 1999: 73.

Diagnosis. Elongate ophidiid with tapering tail. Scales on body, present or reduced on head. Median fins confluent. Pelvic fins with two rays in each. Mouth terminal. Infraorbital bones fragile and much expanded, almost covering maxillaries. Orbit large, equal in length to snout. Eye large, bulged, eye lens degenerated, except large in $L$. lentibus n. sp. Infraorbital, supraorbital and preopercular head canals extremely widened, covered with skin (when preserved), containing small pores. Opercular spine pointed, but weak. Posttemporal with a posterior, flap-like extension reaching beyond the opercle, bearing posterior part of supraorbital canal. Anterior nostril midway between upper lip and posterior nostril. Teeth small and pointed in irregular rows. No fangs. A single median basibranchial tooth-plate. 17-22 long gill rakers. 


\section{Key to species of Leucicorus}

1a Extensive squamation on opercle, preopercle and occiput; transversal scale rows $\geq 25$; inner face of otolith more strongly con-

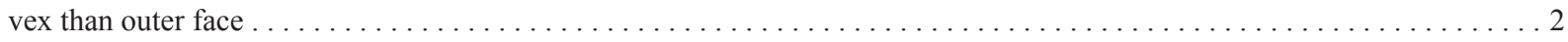

1b Reduced squamation on opercle, preopercle and occiput; transversal scale rows $\leq 21$ (not considering ROV live photographs);

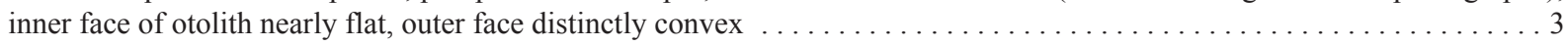
Dorsal fin rays 110-114; anal fin rays 96-99; vertebrae 68-69; transversal scale rows $35-40 \ldots \ldots \ldots \ldots$. . . . . . . . Dorsal fin rays 97; anal fin rays $73-80$; vertebrae 62 ; transversal scale rows $25 \ldots \ldots \ldots \ldots \ldots \ldots$ gerringerae $\mathbf{n} . \mathbf{s p .}$ Dorsal fin rays 88-94; anal fin rays $68-80$; no eye lens or lens smaller than $10 \%$ of black eye; OL:OH $=1.2-1.55$

atlanticus Dorsal fin rays 105 ; anal fin rays 87 ; lens at least $50 \%$ of black eye; $\mathrm{OL}: \mathrm{OH}=1.73 \ldots \ldots \ldots \ldots \ldots \ldots \ldots \ldots \ldots$ lentibus $\mathbf{n} . \mathbf{s p}$.

\section{Leucicorus atlanticus Nielsen, 1975}

Table 1, Figs. 1A, 2C, 3A-D, 5

Leucicorus atlanticus Nielsen, 1975: 113, fig. 1.

Leucicorus atlanticus: Hureau \& Nielsen 1981: 16; Nielsen \& Møller 2008: 29.

Material examined (22 specimens, SL 48-240 mm).

Holotype: ZMUC P771813, 154 mm SL, male, Cayman Trench, 1900’N, 80³8’W, R/V Akademik Kurchatov, cr. 14, st. 1243, Sigsbee trawl, 6400-6800 m, 16. Mar. 1973.

Paratypes (17 specimens): UF 230276 (former UMML 30276), $205 \mathrm{~mm} \mathrm{SL}$, female, Puerto Rico Trench, $22^{\circ} 02^{\prime} \mathrm{N}, 65^{\circ} 10^{\prime} \mathrm{W}, \mathrm{R} / \mathrm{V}$ Pillsbury, st. $1374,41^{\prime}$ otter trawl, 5541-5563 m, 2 July 1971. IORAS 02295, 110-151 $\mathrm{mm}$ SL and ZMUC P77575, $154 \mathrm{~mm}$ SL, female, Cayman Trench, $18^{\circ} 59^{\prime} \mathrm{N}, 80^{\circ} 30^{\prime} \mathrm{W}, \mathrm{R} / \mathrm{V}$ Akademik Kurchatov, cr. 14, st. 1242-A, Sigsbee trawl, 6800 m, 20 Mar. 1973. IORAS 7 specimens not catalogued (specimens missing), 48-139 mm SL and ZMUC P77585, 125 mm SL, Cayman Trench, $19^{\circ} 05^{\prime} \mathrm{N}, 80^{\circ} 29^{\prime} \mathrm{N}, \mathrm{R} / \mathrm{V}$ Akademik Kurchatov, st. cr. 14, 1259, Sigsbee trawl, 6800-6500 m, 22 Mar. 1973. IORAS 02296, 2 specimens, 79-152 mm SL and ZMUC P77586, 78 mm SL, Cayman Trench, 1944'N, 76²' 'W, R/V Akademik Kurchatov, cr. 14, st. 1266, Sigsbee trawl, 5900-6300 m, 24 Mar. 1973. IORAS 02297,120+ mm SL, Cayman Trench, $1^{\circ} 38^{\prime} \mathrm{N}, 76^{\circ} 40^{\prime} \mathrm{W}$, R/V Akademik Kurchatov, cr. 14, st. 1267 Sigsbee trawl, 6740-6760 m, 25 Mar. 1973. IORAS not catalogued (specimen missing), $135 \mathrm{~mm}$ SL, Yucatan Trench, $20^{\circ} 08^{\prime} \mathrm{N}, 84^{\circ} 30^{\prime} \mathrm{W}, \mathrm{R} / \mathrm{V}$ Akademik Kurchatov, cr. 14, st. 1272, Sigsby trawl, $4580 \mathrm{~m}$, 28 Mar. 1973.

Additional material: MNHN 1979-689, $224 \mathrm{~mm} \mathrm{SL}$, Northeast Atlantic Ocean, 10 $46.23^{\prime} \mathrm{N}, 42^{\circ} 40.41^{\prime} \mathrm{W}$, Campagne Biovema, st. B, benthic trawl, 5100 m, 19 Nov. 1977. VIMS 6857, 183 mm SL, female, Silver Abyssal

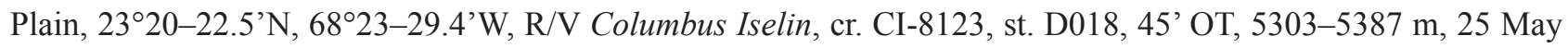
1981. BMNH 2020.11.26.2, 240 mm SL, female, Northeast Atlantic Ocean, $38^{\circ} 00^{\prime} \mathrm{N}, 11^{\circ} 32.7^{`} \mathrm{~W}, \mathrm{R} / \mathrm{V}$ Discovery, st. 11911\#7, OTSB, 5035 m, 26 Sep. 1989. ZMUC P771571, 87 mm SL, unripe, Solomon Sea, 7²49.4’S, 156 02.8’'E, Galathea 3 exp., st. 061228-01, 1.2 m Agassiz trawl, 4350-4450 m, 2 Dec. 2006.

Diagnosis. Dorsal fin rays 82-94, much reduced squamation on preopercle and opercle and occiput almost naked; $18-20$ scale rows on trunk above beginning of anal fin. Black eye comparatively small (10-13.5\% HL), without or minute lens $<10 \%$. Otolith roundish, massive, $\mathrm{OL}: \mathrm{OH}=1.2-1.55$, inner face flat, outer face strongly convex.

Comparison. L. atlanticus is most similar to L. gerringerae by the number of vertebrae and anal fin rays. They differ by the reduced squamation of the occiput in L. atlanticus and in the anal-fin origin placed below dorsal fin rays 15-18 vs 19-21 in L. gerringerae. It further differs in the lower number of transversal scales (18-20 vs 25), more compressed otolith (OL:OH $=1.2-1.55 v s$ 1.62) with the inner face flat and the outer face strongly convex ( $v s$ inner face of otolith convex and outer face slightly convex or flat). It differs from L. lentibus by having fewer dorsal-fin (82-94 vs. 105) and anal-fin (68-80 vs. 87) rays, as well as minute or absent eye lenses $(0-10 \%$ of black eye $v$ s $57 \%$ ).

Description. The principal meristic and morphometric characters are shown in Table 1. Body compressed and elongate with tapering tail. Head broad and somewhat depressed with thin fragile bones. Scales often missing, but scale-pockets show a fully scaled body with about 18 to 20 scales transversely across trunk above beginning of anal fin. Head with scaleless occiput and a few scales on opercle and preopercle. Anterior nostril situated midway 
between upper lip and posterior nostril. Snout equal in length to horizontal orbit. Horizontal length of orbit twice as long as high; lens poorly developed ( $<10 \%$ of diameter of black eye) or absent. Upper jaw ends just below posterior margin of orbit. Opercular spine thin and pointed, almost covered by skin. Upper branch of anterior gill arch with 4-5 knob-like and one long developed raker, a long developed raker in the angle and lower branch with 8-10 long developed and 5-7 knob-like rakers or, 9-12 long developed rakers and 18-21 rakers of both types in total. 1-3 pseudobranchial filaments.

Otolith (Fig. 3A-D). Moderately large otoliths up to $6.2 \mathrm{~mm}$ in length (holotype $=5.8 \mathrm{~mm}$ ) with oval to round shape (otolith length : height $=1.20-1.55$, mostly $<1.3$ ). Ventral rim regularly curved; dorsal rim variable, broadly rounded or with broad, obtuse, pre- to mediodorsal angle; anterior and posterior rims rounded. Inner face flat, outer face strongly convex; otolith height : thickness $=1.75-2.2$. Sulcus horizontal, shallow, short, with single well-defined colliculum; otolith length : sulcus length $=2.52-2.93$; sulcus length : height $=2.0-2.5$. Ventral furrow variably expressed, mostly wide and weak; no distinct dorsal depression.

Distribution (Fig. 5). Known from eight localities in the West Indies (19 specimens from 4580-6800 m), two localities in the Northeast Atlantic Ocean (two specimens from 5035-5100 m) and one location from the Solomon Sea, SW Pacific (4350-4450 m). Leucicorus atlanticus is the deepest living species in the genus.

\section{Leucicorus gerringerae n.sp.}

Table 1, Figs. 1B, 2B, 3E-F, 5

Leucicorus atlanticus: Sêret \& Andreata 1992: 92; Mincarone et al. 2008: 57.

Material examined (2 specimens, SL 214-235 mm).

Holotype: VIMS 42888, 235 mm SL, male, Silver Abyssal Plain, 2320-22.5’ N, 68²3-29.4’ W, R/V Columbus Iselin, cr. CI-8113, st. D018, 45’ OT, 5303-5387 m, 25 May 1981.

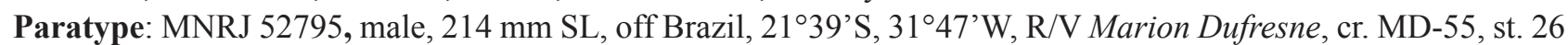
CP 44, beam trawl, 4500-4510 m, 18 May 1987.

Diagnosis. Dorsal fin with 97 rays, anal fin with 73-80 rays and $62(13-14+48-49)$ vertebrae. Head squamation extensive on opercle, preopercle and occiput. 25 scales transversely across trunk above the anal-fin origin. Bluish eyes large $(15-19 \% \mathrm{HL})$, without lens. Otolith elongate $(\mathrm{OL}: \mathrm{OH}=1.62)$, with inner and outer faces equally convex.

Comparison. L. gerringerae is most similar to L. lusciosus with the extensive head squamation; however, it differs from L. lusciosus by having fewer dorsal-fin (97 vs. 110-114) and anal-fin (73-80 vs. 87-99) rays, larger head scales (2.0-2.5 mm vs $\sim 1 \mathrm{~mm}$ ) and fewer scales across trunk above beginning of anal fin (25 vs. 35-40). It differs from L. lentibus by having an extensive head squamation, fewer rays in dorsal (82-94 vs. 105) and anal (73-80 vs. 87) fins and by lacking an eye lens. It differs from the sympatric $L$. atlanticus in having complete head squamation (vs reduced on occiput), higher number of dorsal-fin rays (97 vs 82-93), larger eye size (15-19\% HL vs 10-13.5\% HL except one eye in one case $18.4 \% \mathrm{HL})$, and the more elongate otolith $(\mathrm{OL}: \mathrm{OH}=1.62)$ with equally convex inner and outer faces (vs roundish otolith, $\mathrm{OL}: \mathrm{OH}=1.2-1.55$, with flat inner face and strongly convex outer face).

Description. The principal meristic and morphometric characters are shown in Table 1. The description is based on the holotype; characters in which the paratype differ from the holotype are given in brackets. Body elongate and compressed with tapering tail; head broad with dorsal profile straight except for a slight concavity above eyes; head bones thin and fragile. Anterior nostril placed midway between upper lip and posterior nostril and the larger posterior nostril close to orbit. Orbit equal in length to snout. Black eye about 15 to $19 \%$ of HL; no eye lens discernible. Opercular spine thin and pointed. Body fully scaled, with 25 scale rows transversely above beginning of anal fin, head with scales on opercle, preopercle and occiput. Dorsal-fin origin above anterior part of pectoral fin; anal-fin origin below dorsal fin ray 21(19), much closer to tip of snout than to base of caudal fin and with a preanal length ca. $40 \%$ SL. Pelvic fins each with two tightly joined rays. Pectoral fins placed on midbody. Mouth terminal; upper jaw ends below posterior edge of orbit; supramaxilla well developed. Anterior gill arch with four knob-like and one long raker on upper branch, one long raker in the angle between upper and lower branches and lower branch with nine(7) long and five(6) knob-like rakers; longest gill raker almost three times as long as longest gill filament. 2-4 pseudobranchial filaments. The color is brownish grey except for the bluish eyes. 
Axial skeleton (based on radiographs). Precaudal vertebrae 14(13) all with pointed neural spine tips. Anterior neural spine half the length of second spine whereafter the neural spines decrease in length. Six anterior neural spines somewhat depressed. Bases of neural spines 5-14(5-13) enlarged. Parapophyses on precaudal vertebrae 5-14(4-13). Pleural ribs on precaudal vertebrae 3-13(2-12). Epineurals not observed.

Dentition. All dentigerous bones with many, small and pointed teeth arranged in irregular rows. Dentaries and premaxillae with teeth along their entire length with decreasing rows posteriad. Palatines with spindle shaped dentition and vomer 'boomerang'-shaped with rather few teeth. One median basibranchial tooth patch, $6.5 \mathrm{~mm}$ long, 2.5 $\mathrm{mm}$ broad anteriorly and $0.8 \mathrm{~mm}$ broad posteriorly, with dentition similar to that on dentaries.

Otolith (Fig 3E-F). Large otoliths up to $10.5 \mathrm{~mm}$ in length (holotype) with slender, droplet-like shape (otolith length : height $=1.62$ ). Ventral rim shallow; dorsal rim with broad, obtuse, predorsal angle; anterior rim broadly rounded; posterior tip slightly tapering. Inner face about as convex as outer face; otolith height : thickness $=2.3$. Sulcus slightly inclined, shallow, narrow, with single well-defined colliculum; otolith length : sulcus length $=2.28$ 2.88 ; sulcus length : height $=3.3-4.5$. Sulcus connected to anterior-dorsal rim via indistinct channel. Ventral furrow variably expressed; no distinct dorsal depression.

Distribution (Fig. 5). Known from two localities (north of the Bahama Isl. and west of Rio de Janeiro) caught abyssally (4500 to $5303 \mathrm{~m}$ ).

Etymology. The species is named after Dr. Mackenzie Gerringer (State University of New York at Geneseo, USA) for her contribution to the knowledge of the biology of hadal fishes.

\section{Leucicorus lentibus $\mathbf{n} . \mathbf{s p}$.}

Table 1, Figs. 1C, 2D, 3G, 5

Holotype (and only specimen): ZMUC P771812, $170 \mathrm{~mm} \mathrm{SL}$, female, off Hawai ${ }^{\circ}, 20^{\circ} 01^{\prime} \mathrm{N}, 154^{\circ} 05 \mathrm{~W}, \mathrm{R} / \mathrm{V}$ Vityaz, cr. 29, st. 4313, Sigsbee trawl, 5385-5390 m, 1 Feb. 1959.

Diagnosis. Dorsal fin with 105 rays, anal fin with 87 rays and $64(14+50)$ vertebrae. Transversal scale rows above origin of anal fin 20 (up to 27 rows in presumable life photographs). Reduced squamation on occiput, preopercle and opercle. Diameter of black eye $13 \%$ head length with large eye lens of $57 \%$ of black eye diameter. Otolith with flat inner and convex outer face; $\mathrm{OL}: \mathrm{OH}=1.73$.

Comparison. L. lentibus seems most similar to L. atlanticus with the reduced head squamation and a comparable number of transversal scale rows; however, it differs from $L$. atlanticus by having more dorsal- (105 vs. $82-93)$ and anal-fin rays (87 vs. $68-80)$ and a more slender otolith (OL:OH $=1.73 v s 1.2-1.55)$. It differs from $L$. lusciosus by having reduced head squamation, fewer transversal scale rows (20 vs. 35-40) and fewer dorsal- (105 vs. 110-114) and anal-fin (87 vs. 96-99) rays. It differs from L. gerringerae for its reduced head squamation, and by having more dorsal- (105 vs 97) and anal-fin (87 vs 73-80) rays and the flat inner and convex outer face of the otolith ( $v s$ convex inner face and slightly convex to flat outer face). It differs from all the three congeners in the presence of a large eye lens ( $57 \%$ of black eye $v s 0-10 \%)$.

Description. The principal meristic and morphometric characters are shown in Table 1. Body elongate and compressed with tapering tail; head broad and flat with a slight concavity above the eyes; head bones thin and fragile. Diameter of black eye $13 \%$ head length; the distinct, light, oval lens is $57 \%$ the diameter of the black eye. Opercular spine thin and broadly pointed. Scales and scale pockets show a fully scaled body; 20 transversal scale rows from anal-fin origin; head with reduced squamation on occiput, preopercle and opercle. Dorsal-fin origin above anterior part of pectoral fin; anal-fin origin distinctly closer to tip of snout than to base of caudal fin; pelvic fins each with two tightly joined rays. Mouth terminal with upper jaw ending below posterior part of orbit. Anterior gill arch with four knob-like rakers on upper branch, one long raker in the angle and lower branch with nine long and four knob-like rakers; longest gill raker 3-4 times the length of the longest gill filament; two pseudobranchial filaments. After sixty-two years of preservation in alcohol the specimen is brownish grey with blue eye balls.

Axial skeleton (based on radiographs). Precaudal vertebrae 14, all with pointed neural spines. Anterior neural spine half the length of the second one. The six anterior neural spines slightly depressed. Basis of neural spines 4-14 enlarged. Parapophyses on precaudal vertebrae 8-14. Pleural ribs on precaudal vertebrae 3-14. Epineurals not observed. 

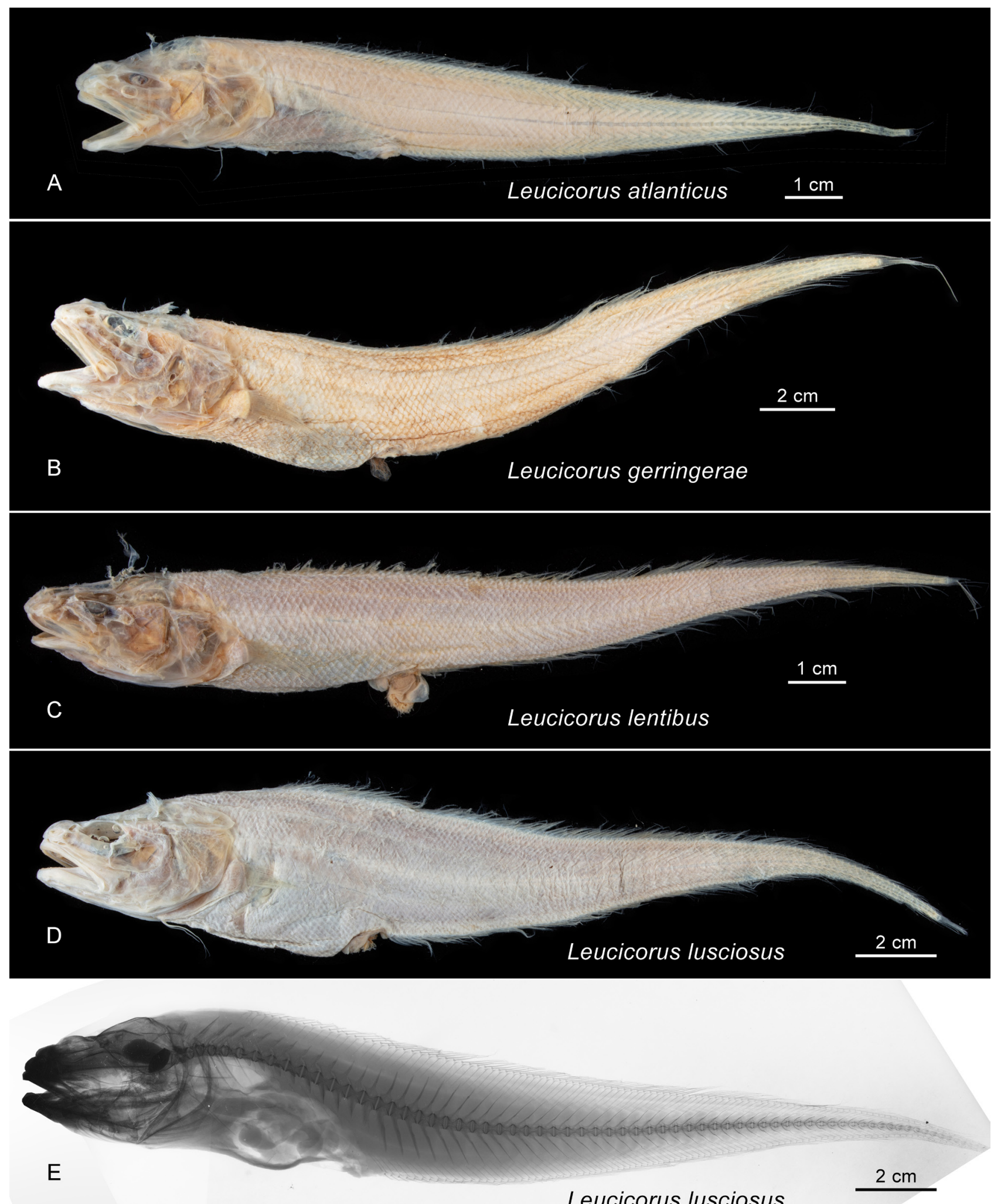

Leucicorus lusciosus

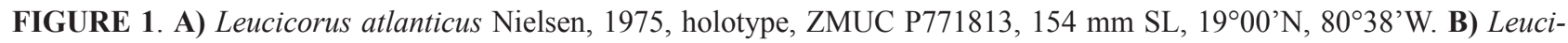
corus gerringerae n. sp., holotype, VIMS 42888, 235 mm SL, 2320-22.5' N, 68²3-29.4' W. C) Leucicorus lentibus n. sp., holotype, ZMUC P771812, 170 mm SL, 2001'N, 154º5'W. D) Leucicorus lusciosus Garman, 1899, ZMUC P771814, 225

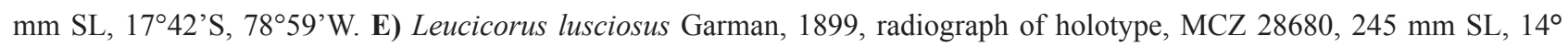
$46^{\prime} \mathrm{N}, 98^{\circ} 40^{\prime} \mathrm{W}$. 

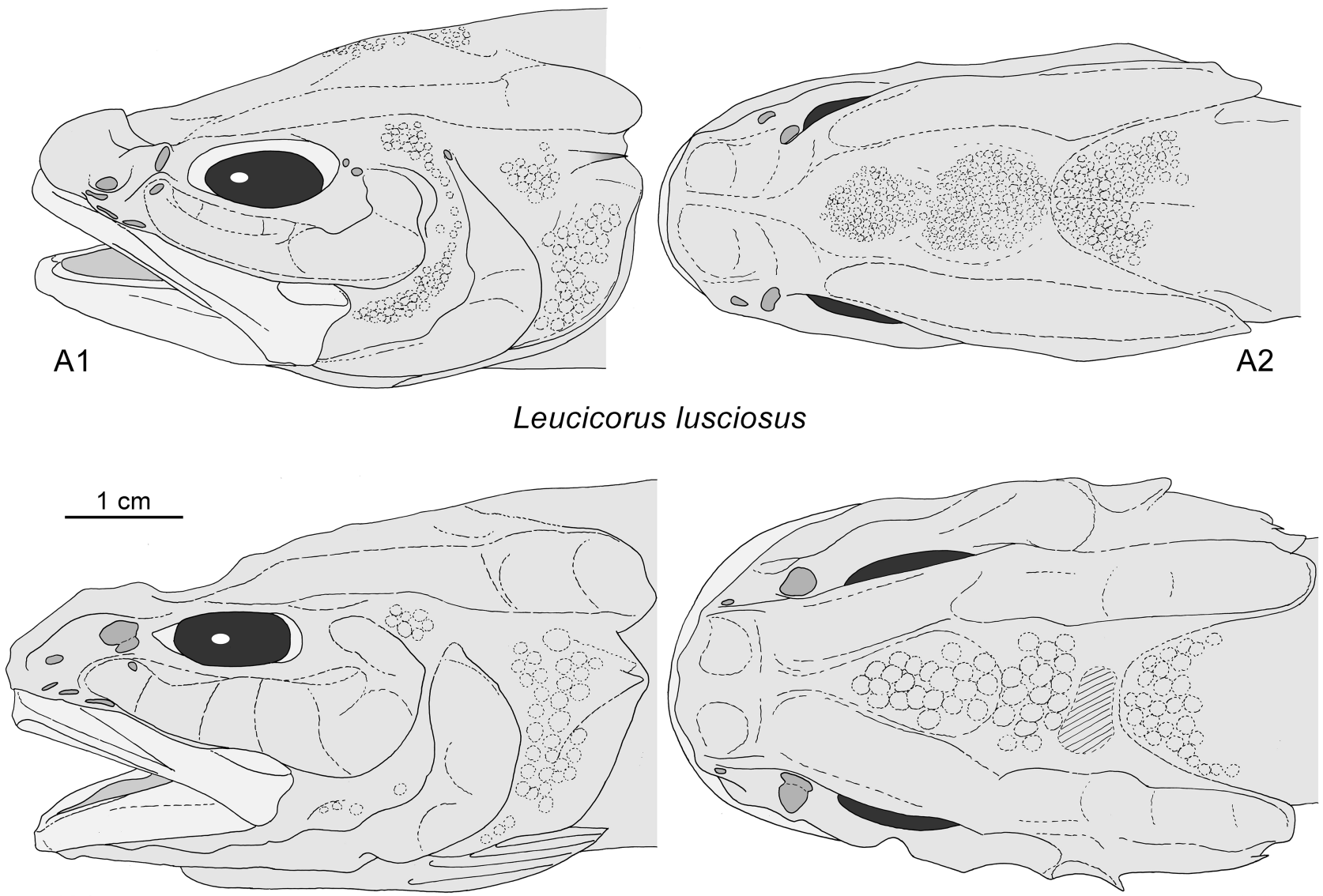

B1

Leucicorus gerringerae

C1
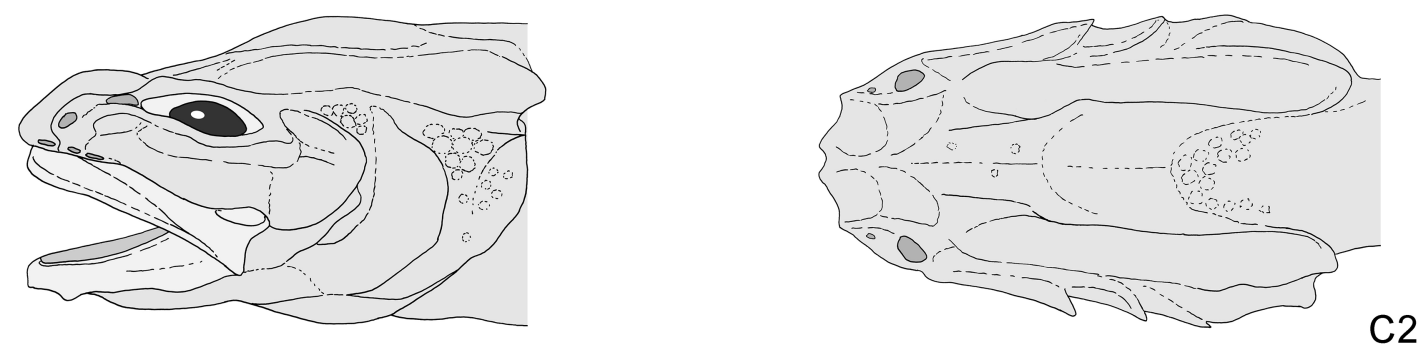

Leucicorus atlanticus
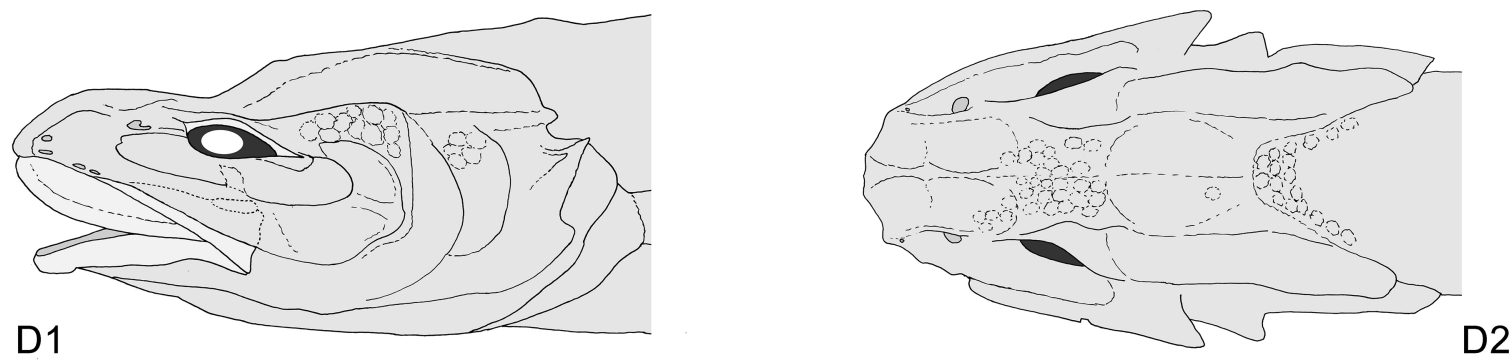

\section{Leucicorus lentibus}

FIGURE 2. Head drawings (lateral and top): A) Leucicorus lusciosus Garman, 1899, ZMUC P771814, 225 mm SL, 1742'S, 7859'W. B) Leucicorus gerringerae n. sp., holotype, VIMS 42888, 235 mm SL, 2320-22.5’ N, 68²3-29.4' W. C) Leucicorus atlanticus Nielsen, 1975, holotype, ZMUC P771813, $154 \mathrm{~mm} \mathrm{SL}, 1^{\circ} 00^{\prime} \mathrm{N}, 80^{\circ} 38^{\prime} \mathrm{W}$. D) Leucicorus lentibus n. sp., holotype, ZMUC P771812, $170 \mathrm{~mm}$ SL, 2001’N, $154^{\circ} 05 \mathrm{~W}$. 
Dentition. All dentigerous bones with many close-set, pointed teeth in irregular rows. Premaxillae and dentaries with teeth along their full length. Vomer boomerang-shaped. Palatines spindle-shaped. A single long and narrow basibranchial tooth patch.

Otolith (Fig. 3G). Large otolith of $8.2 \mathrm{~mm}$ in length (holotype) with slender, droplet-like shape (otolith length : height $=1.73$ ). Ventral rim shallow; dorsal rim with broad, rounded, predorsal angle; anterior rim broadly rounded; posterior tip slightly tapering, rounded. Inner face nearly flat; outer face convex; otolith height : thickness $=1.9$. Sulcus straight, shallow, narrow, with single well-defined colliculum; otolith length : sulcus length $=2.18$; sulcus length : height $=4.4$. Sulcus connected to the anterior-dorsal rim via collicular crest. Ventral furrow very close to ventral rim of otolith; dorsal depression small.

Distribution (Fig. 5). Known from the holotype caught in a bottom working trawl at a depth 5385-5390 m off Hawaii.

Etymology. From lentibus (Latin) $=$ lens bearing, referring to the presence of a large eye lens.

\section{Leucicorus lusciosus Garman, 1899}

Table 1, Figs. 1D-E, 2A, 3J-K, 5

Leucicorus lusciosus Garman, 1899: 146.

Leucicorus lusciosus: Grey 1956: 218; Nielsen 1975: 109.

Material examined (2 specimens, SL 225-245 mm and a radiograph of SIO 81-148).

Holotype: MCZ 28680, $245 \mathrm{~mm}$ SL, male, eastern tropical Pacific, $14^{\circ} 46^{\prime} \mathrm{N}, 98^{\circ} 40^{\prime} \mathrm{W}$, R/V Albatross, st. 3415, beam trawl, 3436 m, 10 Apr. 1891. Non-types: ZMUC P771814, 225 mm SL, female, off Peru, 17²'’S, 78 59’W, R/V Akademik Kurchatov, st. 271, Sigsbee trawl, 2710-3080 m, 20 Dec. 1968. Radiograph and otolith of SIO 81-148, 251+ mm SL, female, Panama Basin, $5.175^{\circ} \mathrm{N}, 81^{\circ} 68^{\prime} \mathrm{W}, \mathrm{R} / \mathrm{V}$ Melville, $40^{\prime}$ otter trawl, PA 3, 3900-4000 m, 31 Mar. 1931.

Diagnosis. Dorsal-fin rays 110-114 and anal-fin rays 87-99; total vertebrae 68-69. Extensive squamation on opercle, preopercle and occiput; 35 to 40 transversal scale rows on trunk above beginning of anal fin. Otolith elongate $(\mathrm{OL}: \mathrm{OH}=1.65-1.75)$, with inner face more strongly convex than outer face.

Comparison. L. lusciosus is most similar to L. gerringerae, due to the extensive squamation on head; however, it differs from L. gerringerae by having more dorsal- (110-114 vs. 97) and anal-fin (96-99 vs. 73-80) rays, smaller scales on head ( 1 mm vs $2.0-2.5 \mathrm{~mm}$ ) and more scale rows on trunk above anal-fin origin (35-40 vs. 24-25). It differs from both $L$. atlanticus and L. lentibus by the extensive head squamation and a high number of transversal scale rows above origin of anal fin.

Description. The principal meristic and morphometric characters are shown in Table 1. Body elongate and compressed with tapering tail; head broad with dorsal profile straight except for a slight concavity above eyes; head bones thin and fragile. Anterior nostril placed midway between upper lip and posterior nostril and the larger posterior nostril close to orbit. Orbit equal in length of snout; lens poorly developed or absent. Opercular spine thin and pointed. Body fully scaled, head with scales on opercle, preopercle and occiput. Pelvic fins each with two tightly joined rays. Pectoral fins placed on midbody. Mouth terminal; upper jaw ends below posterior edge of orbit; supramaxilla well developed. Anterior gill arch with 9-10 long developed and eight knob-like rakers. 1-2 pseudobranchial filaments.

Otolith (Fig 3J-K). Large otoliths up to $11.4 \mathrm{~mm}$ in length with slender, droplet-like shape (OL:OH $=1.65-$ 1.75). Ventral rim shallow; dorsal rim higher, broadly rounded, with obtuse pre- to mediodorsal angle; anterior rim broadly rounded; posterior tip slightly tapering. Inner face convex, outer face flat to slightly convex; otolith height : thickness $=2.0-2.6$. Sulcus straight, shallow, narrow, with single well-defined colliculum; otolith length : sulcus length $=1.80-1.9 ;$ sulcus length $:$ height $=3.6-4.3$. Sulcus not connected to anterior-dorsal rim. Ventral furrow well expressed, close to ventral otolith rim; indistinct dorsal depression.

Distribution (Fig. 5). Known from three localities in the East Pacific Ocean. Caught in bottom trawls at 27104000 meters. Leucicorus lusciosus is the only species in the genus caught at bathyal depth. Two sightings by ROV from the NOAA ship Okeanos Explorer campaign south of Hawaii and near the southern Line Islands may also belong to L. lusciosus (see below). 

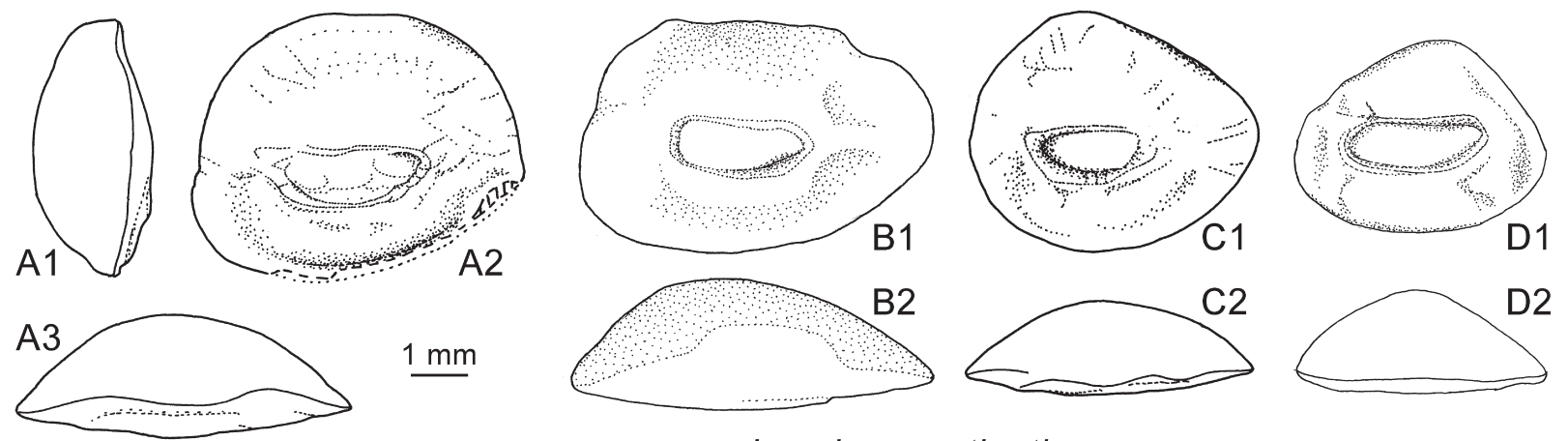

\section{Leucicorus atlanticus}
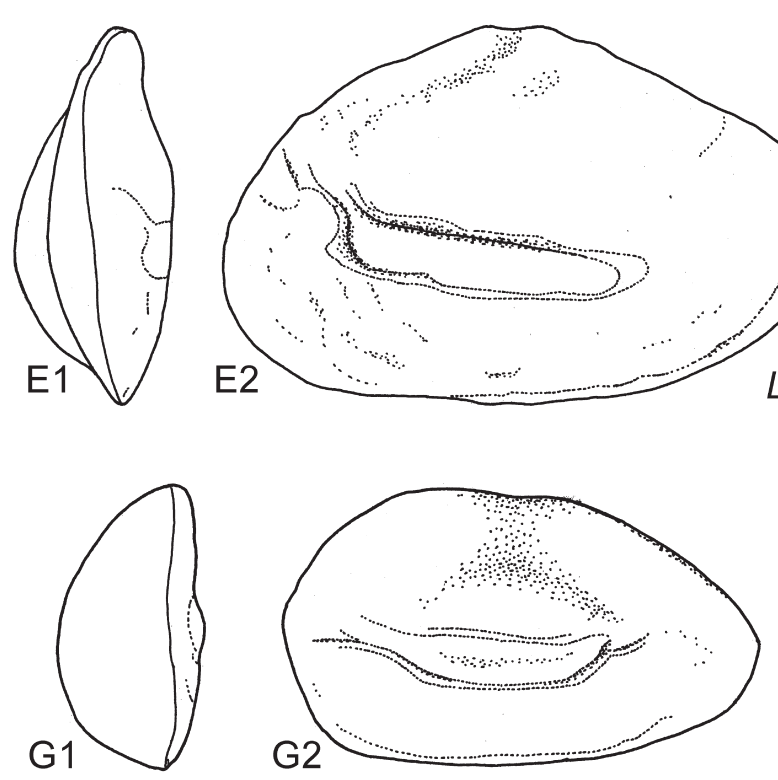

G1

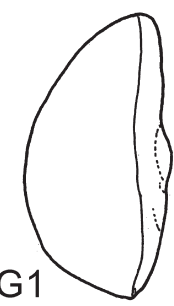

H1

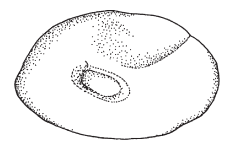

$\mathrm{H} 2$

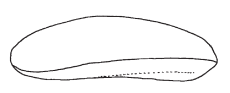

G3

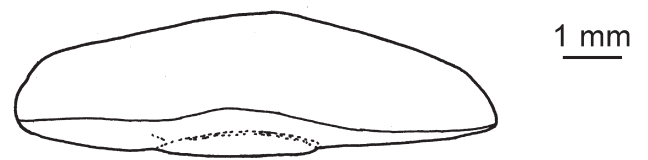

11

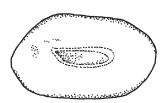

12

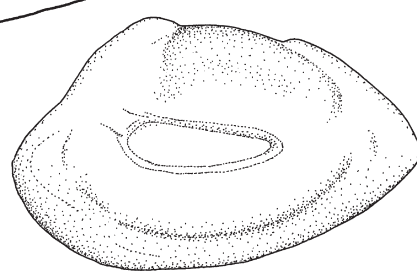

Leucicorus lentibus
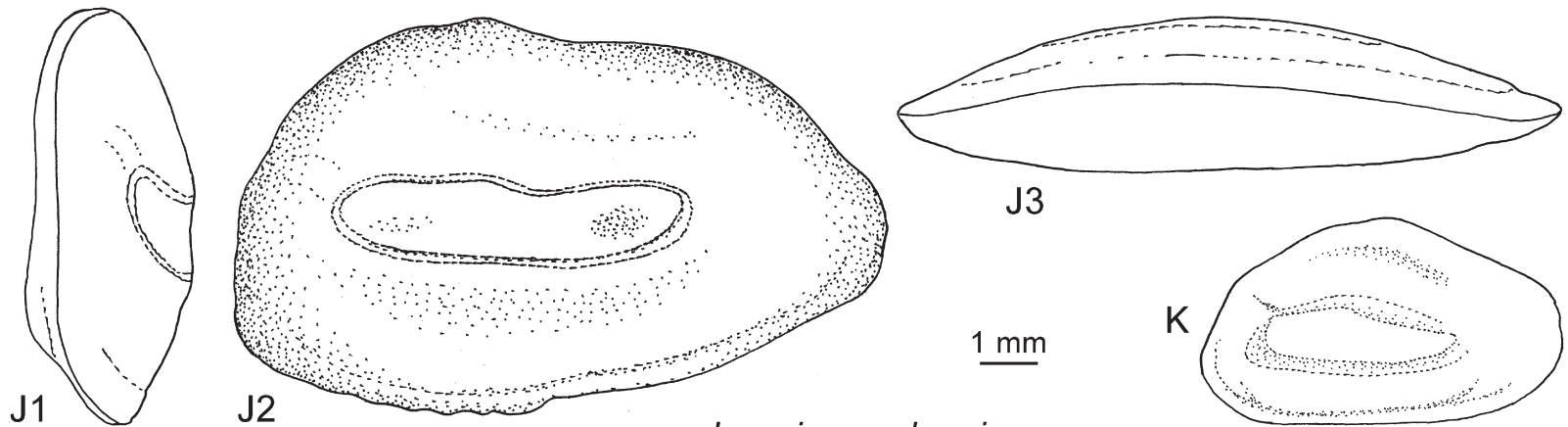

\section{Leucicorus lusciosus}

FIGURE 3. Otolith drawings: A-D) Leucicorus atlanticus Garman, 1899; A, holotype, ZMUC P771813 (A1 anterior view, A2 medial view, A3 dorsal view); B, ZMUC P77585 (B1 medial view, B2 dorsal view); C, VIMS 06857 (C1 medial view, C2 dorsal view); D, BMNH 2020.11.16.1 (D1 medial view, D2 dorsal view). E-F) Leucicorus gerringerae n. sp.; E, holotype, VIMS 42888 (E1 anterior view, E2 medial view, E3 dorsal view); F, MNRJ 52795 (medial view). G) Leucicorus lentibus n. sp., holotype, ZMUC P771812 (G1 anterior view, G2 medial view, G3 dorsal view). H-I) Leucicorus sp.; H, SMF 28854,85 mm SL (H1 medial view, H2 dorsal view); I, SMF 28854, 75 mm SL (I1 medial view, I2 dorsal view). J-K) Leucicorus lusciosus Garman, 1899; J, SIO 81-148 (J1 anterior view, J2 medial view, J3 ventral view); K, ZMUC P771814, medial view. 


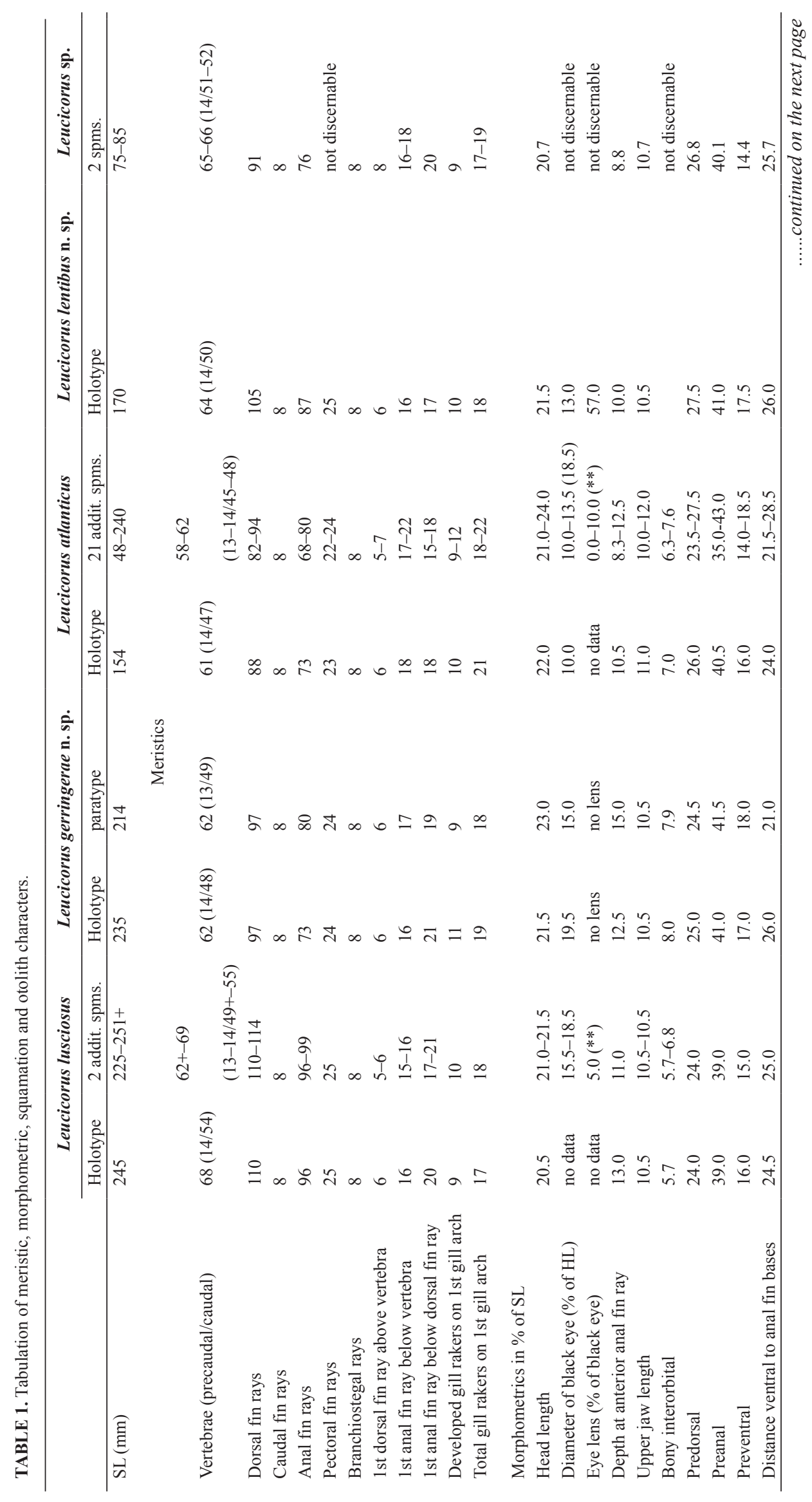




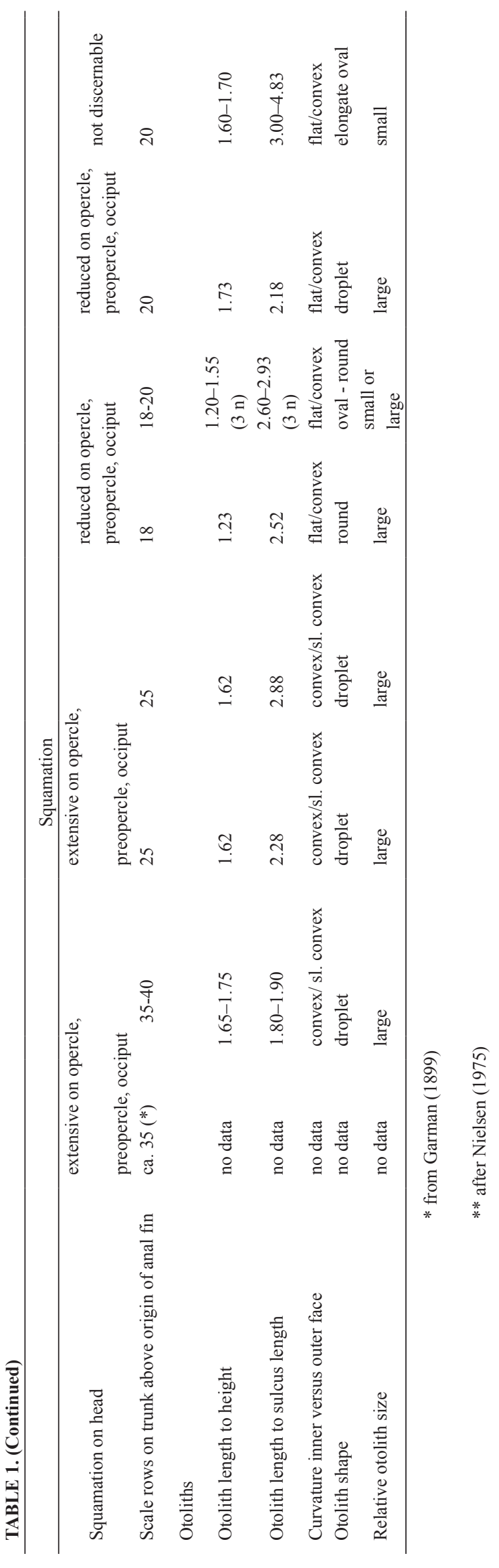




\section{Leucicorus sp.}

Table 1, Figs. 3H-I, 5

Material examined. 2 specimens: SMF 28854, 75 and $85 \mathrm{~mm}$ SL, unripe, Arabian Sea, $10^{\circ} 01.56^{\prime} \mathrm{N}, 65^{\circ} 02.83^{\prime} \mathrm{E}$, GEOMAR Exped. 1998 R/V Sonne, cruise 129, free vehicle trap, 4425 m, 14 Feb. 1998.

These two specimens can undoubtedly be referred to Leucicorus, but they are juveniles and not in good condition (especially the larger specimen), thus preventing a specific identification. The otoliths are small and with a flat inner and a convex outer face similar to L. atlanticus and L. lentibus. They are characterized by an extremely small sulcus (otolith length : sulcus length $=3.0-4.8$ ).

They are the only representatives of the genus known from the Indian Ocean.

\section{Live observations}

Table 2, Fig. 4

Fishes of the genus Leucicorus have been rarely caught and hence could be considered to be rare fishes. However, systematic surveys by ROVs of the NOAA Ship Okeanos Explorer at Pacific seamounts resulted in regular sightings of Leucicorus at depths between 3804 and $5767 \mathrm{~m}$. There were 30 confirmed records of Leucicorus species among the 245 records of all fish species seen in the reported depth range of the genus ( $\geq 2500 \mathrm{~m}$ ) during the 2015-2017 CAPSTONE surveys (12.2\% of the observations). Six others were tentatively identified as Leucicorus but lacked photographs or were photographed at too great a distance to confirm the identifications. These were excluded from this analysis. Leucicorus were seen at 9 of the 38 sites (23.7\%) where ROV dives were done in the depth range reported for the genus (Table 2). The genus was seen at Maro Reef in the Northwestern Hawaiian Islands, the Karin Seamounts near Johnston Atoll, north of Jarvis Island in the Line Island, and Utu Seamount in the northern region of the America Samoa Exclusive Economic Zone (Fig. 5). The largest number of sightings was in the region of the Mariana Archipelago, including the flanks of the Mariana Trench, with 20 sightings at five seamounts in the region (Table 2, Fig. 5). Note that the ROV was rated to $6000 \mathrm{~m}$, not even half of the maximum depth of the Trench, so exploration of hadal depths there was not possible.

The depth range of CAPSTONE observations of the genus was 3804-4983 m. Temperatures in situ were 1.2898 $-1.6308^{\circ} \mathrm{C}$, salinities were $34.6782-34.7052$, and the dissolved oxygen concentrations were $4.1601-5.4512 \mathrm{mg} /$ L. Size estimates of the fish were in the $10-30 \mathrm{~cm}$ size category, but more accurate measurements were not possible. The habitats where the fish were observed were primarily either manganese-encrusted rock of various forms, or sediment overlying basalt bedrock, pillow-lava formations, boulder, or cobble. The CAPSTONE expeditions did not survey low-gradient, heavily sedimented, abyssal plain habitats.

The fish seen were solitary, with one exception of an observation of two individuals at $3857 \mathrm{~m}$ at a seamount in the Mariana Archipelago. Most swam slowly, a few centimeters to about a meter above the bottom, while a few others remained stationary just above the substrate. None rested on the bottom. No behavior that could be interpreted as feeding or reproduction was seen. One fish had a significant damage to the head, including a missing eye that we interpret as the result of a predator's attack. It was seen at $4570 \mathrm{~m}$ on a Clipperton Fracture Zone ridge to the Northwest of Jarvis Island in the southern Line Islands. Potential predators seen during that dive were a large Coryphaenoides species (armatus or yaquinae), and a Bathysaurus mollis, but we have no evidence that either of those was the predator involved.

In addition to the records from the CAPSTONE expeditions, Drazen et al. (2021, supplementary material) reported a Leucicorus at $4076 \mathrm{~m}$ from the southeastern Pacific to the south of the Galápagos Islands at $7^{\circ} 04.83^{\prime} \mathrm{S}, 88^{\circ} 21.33^{\prime} \mathrm{W}$.

Specimens of Leucicorus are relatively easily distinguished from other ophidiiform sightings by their large, black and somewhat bulbous eyes, which is unusual for fishes living at such great depth. Most other ophidiiforms, for example Abyssobrotula, Barathrites or Typhlonus, which may also occur at that depth, have usually very small, almost atrophied eyes. Porogadus is the only other ophidiid genus regularly occurring at that depth with "normal" eye size, which, however, remains comparatively small compared to the eye size of Leucicorus. In the original description of Leucicorus lusciosus, Garman (1899) described the conditions of the eyes of L. lusciosus as "obsolescent without iris nor pupil" and "with the ball greatly reduced and covered with black pigment". He went on to state 


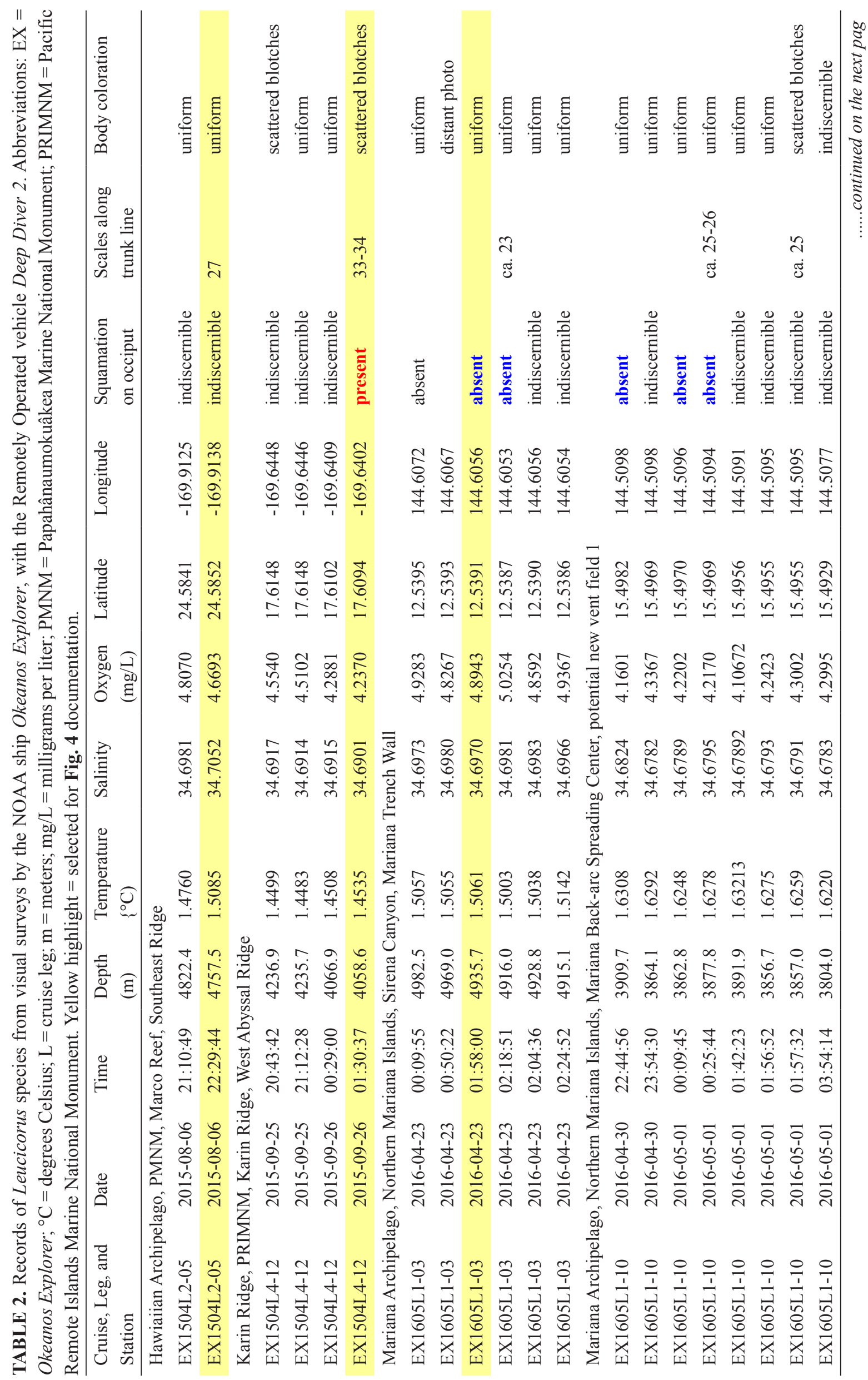




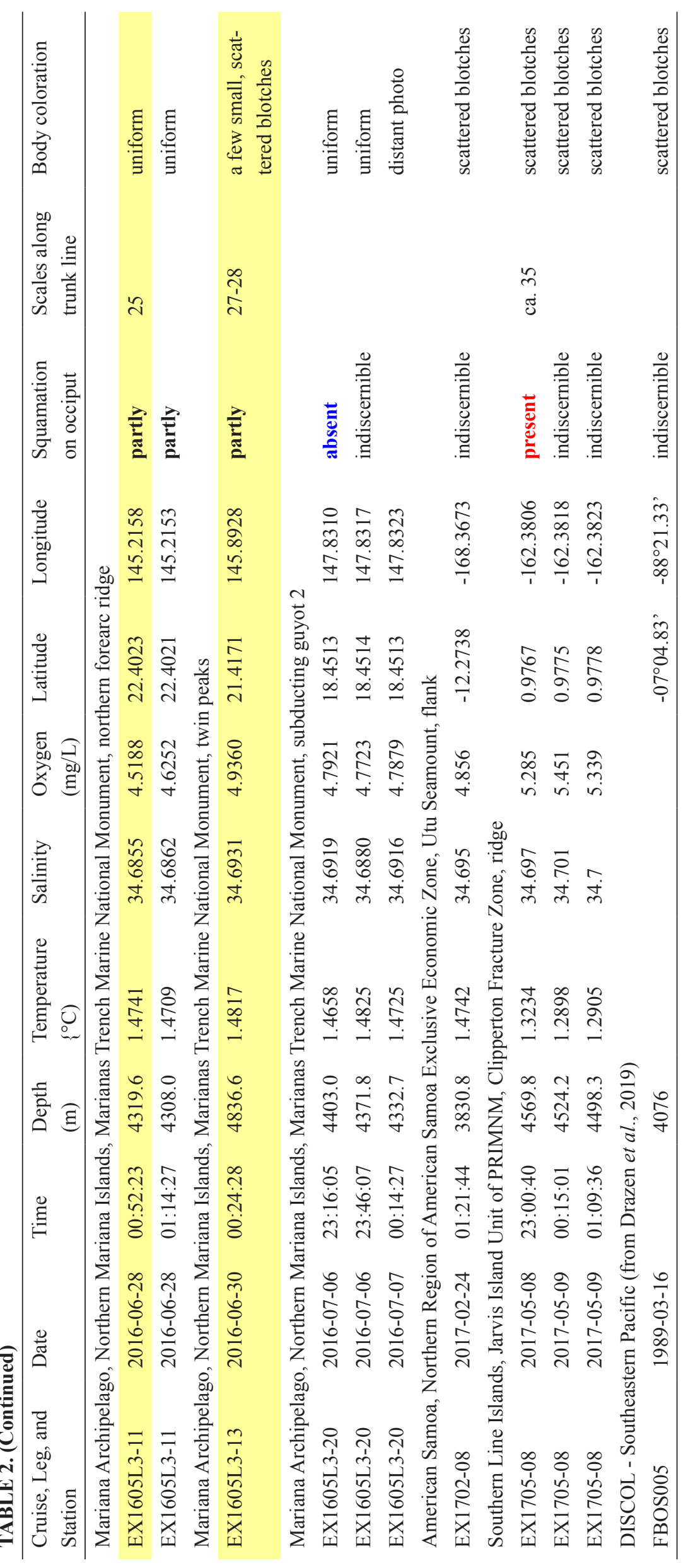


that "the eye differs greatly from that of other species of brotuloids and suggests a possible adaptation to sensation from phosphorescence, or perhaps a modification fitted for the production of phosphorescent light". He considered the eyes degenerated, which contrasts with their large size. Nielsen (1975) studied the eye of specimens of L. atlanticus and observed that the lenses of the eyes of the specimens were much smaller than the diameter of the eye ball $(<10 \%)$, but also that the balls were often found collapsed. A histological examination of the not-collapsed eyes of two specimens revealed a number of peculiarities in the configuration of the eye including only a very small optical nerve. He concluded that the eyes of Leucicorus spp. should be described as modified rather than reduced.
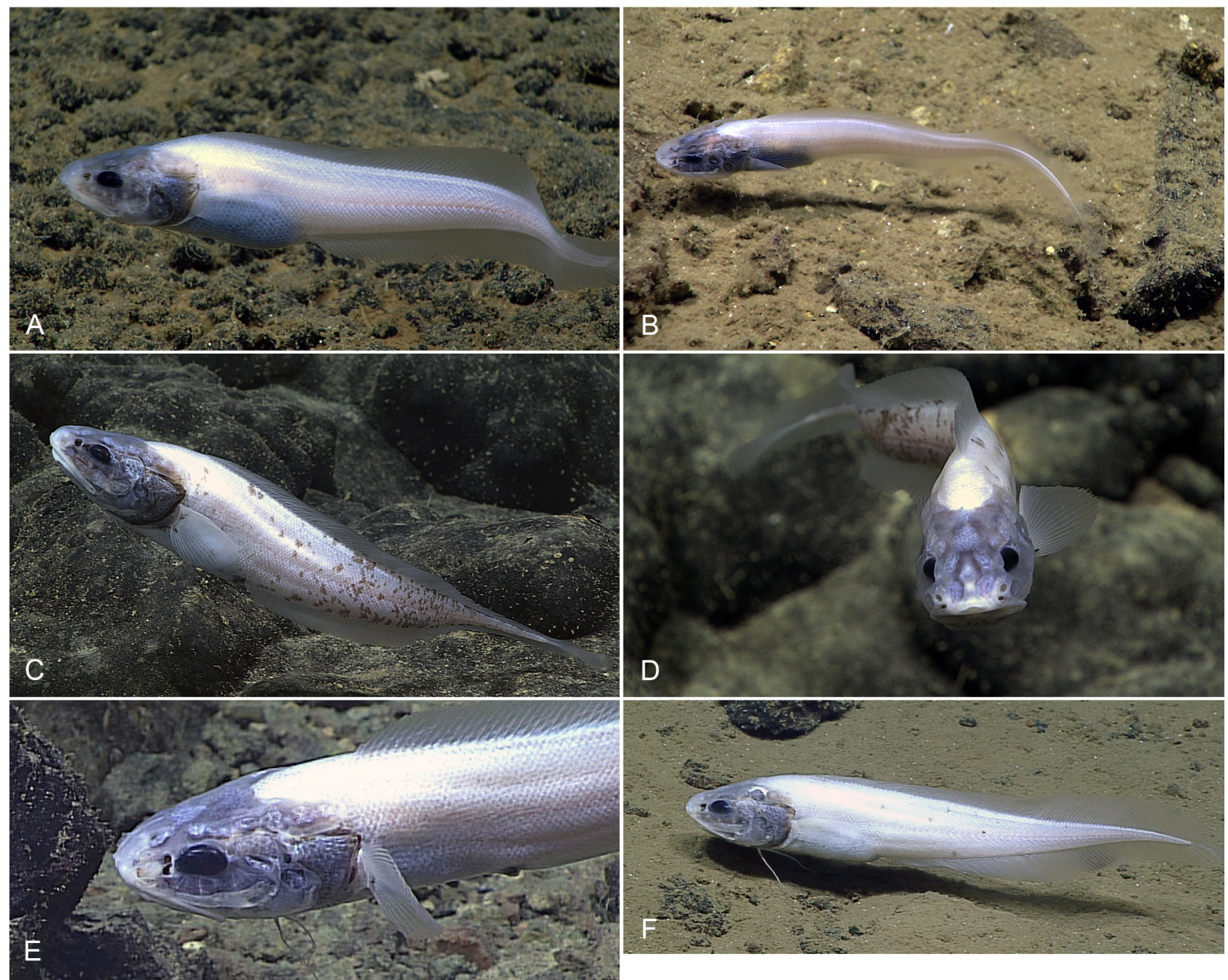

FIGURE 4. Life figures from the Okeanos Explorer ROV: A) Cruise EX1504L2-05, date 2015-08-06, 21:25:02, 4822 m, $24.5841^{\circ}$ lat, - $169.9125^{\circ}$ long; B) Cruise EX1605L1-03, date 2016-04-23, 01:57:55, $4935 \mathrm{~m}, 13.5391^{\circ}$ lat, $144.6056^{\circ}$ long; C-D) Cruise EX1504L4-12, date 2015-09-26, 01:33:06-01:34:24, 4058 m, 17.6094 lat, -169.6402 ${ }^{\circ}$ long; E) Cruise D2-EX1605L311, date 2016-06-28, 00:51:46, 4319 m, 22.4023 lat, 145.2158 long; F) Cruise D2-EX1605L3-13; date 2016-06-30, 00:24:40, $4836 \mathrm{~m}, 21.4171^{\circ}$ lat, $145.8928^{\circ}$ long. Photographs courtesy of NOAA Ocean Exploration.

The unique character appears to be the combination of a large, fluid-filled eye ball, which easily collapses when the fishes are brought to surface and a lens that is, in all but $L$ lentibus, minute or absent. This contrasts with the observations of Marshall (1979) and Warrant \& Locket (2004) that many bathyal (and abyssal) fishes tend to have increased sizes of the pupil and lens in order to capture point-like bioluminescence as the prevailing light sources at depth, which could guide them to prey or mates. A systematic investigation of the eyes of the Leucicorus specimens at hand revealed that, except for the unique holotype of L. lentibus from off Hawai'i (ZMUC P771812), they either lacked a lens or they had only a very small one not exceeding $10 \%$ of the size of the black eye ball. Thus the lenses may be considered degenerated (see above). In some instance only thin, small light-colored tissue was found in the place of a pupil. In the exceptional case of $L$. lentibus, the lens is of normal size, i.e., about $57 \%$ of the diameter of the black eye. We assume that the normal-sized lens in L. lentibus represents the plesiomorphic character state, 
and the small or absent lens in the other species is the derived state. A similar example of lens reduction or loss in ophidiiform fishes is known from cave-dwelling bythitids (Wilkens et al., 1989), but those species live in cavern or cave habitats unlike the deep sea where bioluminescence is known to provide dim, intermittent light. Eye reduction is under different selective pressures in cave and deep-sea taxa (Sumner-Rooney, 2018). It has been suggested that deep-sea species with similar lens reductions, such as Barathronus and Ipnops species, have enhanced abilities to detect bioluminescence at the expense of the ability to detect images (Warrant and Locket, 2004). However, Leucicorus species differ from those species by, and are very unusual in, having dark eyes instead of reflective eyes indicative of the presence of a retinal tapetum lucidum that enhances detection of dim light. Another factor that may be involved in the inter- and intra-specific variability of eye-lens size in Leucicorus is pleiotropy, multiple functions of a single gene. In cave fishes, pleiotropy has been found in a gene that affects eye reduction, but also development of taste buds which are an alternate sensory system important in dark habitats (Krishnan and Rohner, 2017). Thus, there are factors that can inhibit complete loss of structures such as lenses, by causing collateral damage to other, adaptive features (Sumner-Rooney, 2018). Nevertheless, we feel unable to speculate if the apparent reduction of the size of the lens in Leucicorus species represents an adaptive specialization of some sort or indeed a simple degeneration of function.

The size of the black eye was found to be a potential distinctive character between species (i.e., larger in $L$. lucsiosus, L. gerringerae and L. lentibus than in L. atlanticus, see above). However, one large specimen (SL $240 \mathrm{~mm}$ ) of $L$. atlanticus (BMNH 2020.11.26.2) was found to have a large eye on the right side, which is about twice as large as the one on the left side.

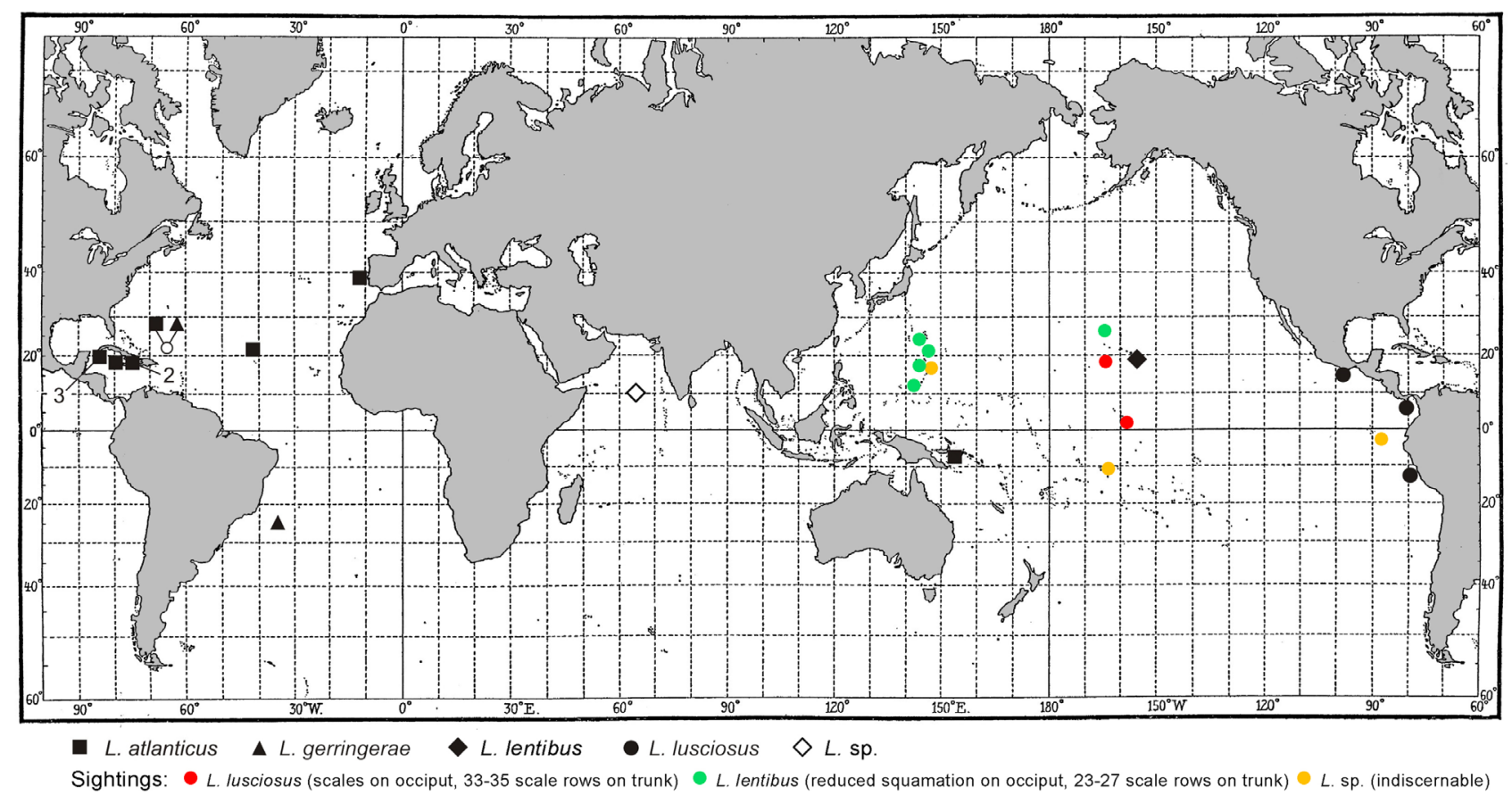

FIGURE 5. Distribution map of Leucicorus species.

While recognition of live photographs and videos pertaining to Leucicorus is relatively easy, recognition of the two main species to be expected in the Pacific, L. lusciosus and L. lentibus, is less straightforward. The recognition of the presence or absence of scale on the occiput, which is a reliable external character, is rarely possible. Another character that we consider helpful in the distinction of the two species is the number of scale rows on the trunk above the origin of the anal fin. Specimens of L. lentibus may have up to 27 scale rows ( 20 in the holotype), while specimens of $L$. lusciosus have more than 33 scale rows. However, this character too is not always discernable. Relative eye size may be another trait but it appears to be even less reliable. We noticed also that some individuals were captured on video with an irregular blotchy or scattered dark coloration pattern on the trunk, while other individuals were uniformly light colored. None of the preserved specimens in collections show any indications of coloration, but that may have disappeared early during the preservation process. No information on color of newly caught specimens is reported for any Leucicorus specimen. It is possible that the apparent color pattern has a teratological cause or is subject to interspecific variations. Recent studies of melanin variations in fish have investigated fishes 
living in the photic zone (Zerulla \& Stoddard, 2021) or have discussed melanin loss or nonsense mutations (Bian et al., 2021) but these studies may not explain the phenomenon observed in the photographs of live Leucicorus specimens. We did notice that the specimens with color signature on the trunk more commonly occur in the Eastand Central-Pacific while the uniformly light-colored ones have been seen mainly in the Central- and West-Pacific. We remain uncertain of any taxonomic value of the trunk coloration because of potential teratological effects (see above) until freshly caught specimens of the two morphotypes can be caught and identified.

\section{Acknowledgments}

We wish to thank the following persons for providing material and data: Natalia Chernova (ZIN), Guy Duhamel (MNHN), Ben Frable (SIO), Eric Hilton (VIMS), Emma Karmovskaya (IORAS), Friedhelm Krupp (SMF), James Macleine (BMNH), Michael Mincarone (UFRJ), Cristiano Moreira (MNRJ), Alexei Orlov (IORAS), Rob Robins (UF), Ralf Thiel (ZMH). Marcus Krag (ZMUC) provided the photographs and Knud Rosenlund (ZMUC) the distribution map. We thank the scientists, technicians and crew who participated in the NOAA ship Okeanos Explorer 2015-2017 CAPSTONE expeditions for the records of live Leucicorus. Bruce Mundy's telepresence participation in those expeditions was supported by the National Marine Fisheries Service Pacific Islands Fisheries Science Center. This is Ocean Research Explorations publication number 11. We sincerely thank Giorgio Carnevale (Torino) and Peter Konstantinidis (Corvallis, Oregon) for their constructive reviews.

\section{References}

Bian, C., Li, R., Wen, Z., Ge, W. \& Shi, Q. (2021) Phylogenetic analysis of core melanin synthesis genes provides novel insights into the molecular basis of albinism in fish. Frontiers in Genetics, 12 (Afrticle 707228) 1-9.

Drazen, J.C., Leitner, A.B., Jones, D.O.B. \& Simon-Lledó, E. (2021) Regional variation in communities of demersal fishes and scavengers across the CCZ and Pacific Ocean. Frontiers in Marine Science, 8, 630616. https://doi.org/10.3389/fmars.2021.630616

Fricke, R. \& Eschmeyer, W.N. (2021) Guide to fish collections. Available from: http://researcharchive.calacademy.org/research/ ichthyology/catalog/collections.asp (accessed 3 August 2021).

Garman, S. (1899) The fishes. Memoirs of the Museum of Comparative Zoology, 24, 1-431.

Gerringer, M.E. (2019) On the success of the hadal snailfishes. Integrative Organismal Biology, 1, 1-18. https://doi.org/10.1093/iob/obz004

Gerringer, M.E., Linley, T.D. \& Nielsen, J.G. (2021) Revision of the depth record of bony fishes with notes on hadal snailfishes (Liparidae, Scorpaeniformes) and cusk eels (Ophidiidae, Ophidiiformes). Marine Biology, 168 (167), 1-9. https://doi.org/10.1007/s00227-021-03950-8

Gregory, T., Lovalvo, D., Mohr, B., McLetchie, K. \& Ryan, M. (2016) Advancing undersea technology. Oceanography, 29(1), Supplement, 52-55.

Grey, M. (1956) The distribution of fishes found below a depth of 2000 meters. Fieldiana: Zoology, 36 (2), 1-337.

Hureau, J.-C. \& Nielsen, J.G. (1981) Les poissons Ophidiiformes des campagnes du N.O. "Jean Charcot" dans l'Atlantique et la Mediterranée. Cybium, 5 (3), 3-27.

Kennedy, B.R.C., Cantwell, K., Malik, M., Kelley, C., Potter, J., Elliott, K., Lobecker, E., Gray, L.M., Sowers, D., White, M.P., France, S.C., Auscavitch, S., Mah, C., Moriwake, V., Bingo, S.R.D., Putts, M., \& Rotjan, R.D. (2019) The unknown and the unexplored: insights into the Pacific deep-sea following NOAA CAPSTONE expeditions. Frontiers in Marine Science, 6,480 . https://doi.org/10.3389/fmars.2019.00480

Krishnan, J. \& Rohner, N. (2017) Cavefish and the basis for eye loss. Philosophical Transactions of the Royal Society B, 372 (20150487), 1-10. https://doi.org/10.1098/rstb.2015.0487

Marshall, N.B. (1979) Developments in deep-sea biology. Blandford Press Ltd, Poole, Dorset, 566 pp.

Mesick, S., Gottfried, S., Reser, B. \& Woodard, K. (2016) Applied excellence in data management. Oceanography, 29 (1), Supplement, 56-57.

Mesick, S., Gottfried, S. Wall-Bell, S.C. \& Jackson, J. (2017) Exploring the ocean through data. Oceanography, 30 (1), Supplement, 48-49.

Mincarone, M.M., Nielsen, J.G. \& Costa, P.A.S. (2008) Deep-sea ophidiiform fishes collected on the Brazilian continental slope, between $11^{\circ}$ and $23^{\circ}$ S. Zootaxa, 1770, 41-64.

Nielsen, J.G. (1974) List of ophidioid fishes from the $14^{\text {th }}$ cruise of the "Akademik Kurchatov" with a new species of Aphyonus. 
Trudy Instituta Okeanologii, 100, 348-353. [translation No. 72 from NOAA, Washington, D.C.]

Nielsen, J.G. (1975) A review of the oviparous ophidioid fishes of the genus Leucicorus, with description of a new Atlantic species. Trudy Instituta Okeanologii, 101, 106-123. [translation No. 74 from NOAA, Washington, D.C.]

Nielsen, J.G., Cohen, D.M., Markle, D.F. \& Robins, C.R. (1999) Ophidiiform fishes of the world (order Ophidiiformes). FAO species catalogue, 18, 1-178.

Nielsen, J.G. \& Møller, P.R. (2008) New and rare deep-sea ophidiiform fishes from the Solomon Sea caught by the Danish Galathea 3 Expedition. Steenstrupia, 30 (1), 21-46.

Quattrini, A.M., Nizinski, M.S., Chaytor, J.D., Demopoulos, A.W. J., Roark, E.B., France, S.C., Moore, J.A., Heyl, T., Auster, P.J., Kinlan, B., Ruppel, C., Elliott, K.P., Kennedy, B.R.C., Lobecker, E., Skarke, A. \& Shank, T.M. (2015) Exploration of the canyon-incised continental margin of the Northeastern United States reveals dynamic habitats and diverse communities. PLoS ONE, 10 (10), e0139904, 1-32. https://doi.org/10.1371/journal.pone.0139904

Sêret, B. \& Andreata, J.V. (1992) Deep-sea fishes collected during cruise MD-55 off Brazil. Cybium, 16 (2), 81-100.

Sumner-Rooney, L. (2018) The kingdom of the blind: disentangling fundamental drivers in evolution of eye loss. Integrative and Comparative Biology, 58, 372-385.

Wilkens, H., Strecker, U. \& Yager, J. (1989) Eye reduction and phylogenetic age in ophidiiform cave fishes. Zeitschrift für zoologische Systematik und Evolutionsforschung, 27, 126-134.

Warrant, E.J. \& Locket, N.A. (2004) Vision in the deep sea. Biological Review, 79, 671-712.

Zerulla, T.C. \& Stoddard, P.K. (2021) The biology of polymorphic melanic side-spotting in poeciliid fishes. Frontiers in Ecology and Evolution, 8 (Article 608289), 1-23. 